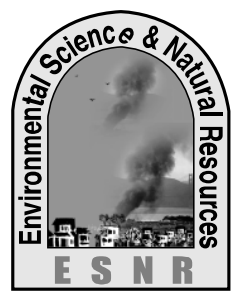

J. Environ. Sci. \& Natural Resources, 5(2): 315 - 322, 2012

ISSN 1999-7361

\title{
Studies on the Development of Mixed Fruit Marmalade
}

\author{
A. K. M. S. Inam ${ }^{1}$, M. M. Hossain ${ }^{2}$, A. A. Siddiqui ${ }^{3}$ and M. Easdani ${ }^{4}$ \\ ${ }^{1}$ Lecturer, Department of Food Engineering and Technology,Hajee Mohammad Danesh Science and \\ Technology University, Dinajpur. 5200. Bangladesh. \\ ${ }^{2}$ Assistant Manager (QC), AST Beverage Ltd., Narayanganj, Bangladesh. \\ ${ }^{3}$ Associate Professor, Department of Food Engineering and Technology, State University of Bangladesh, \\ Dhaka. \\ ${ }^{4}$ Lecturer, Department of Food Engineering and Technology, State University of Bangladesh, Dhaka.
}

\begin{abstract}
This study reports on processing of mixed fruit marmalades from malta, mango and pineapple juices at different ratios. Sensory attributes and storage studies of the mixed fruit marmalades were also evaluated. The fresh and fully mature fruits were used for this experiment. Chemical characteristics such as moisture, ash, acidity, $\mathrm{pH}$, vitamin $\mathrm{C}$, sugar and total soluble solids (TSS) of fruit juices and mixed fruit marmalades were determined. Variations in chemical constituents were observed among the juice and marmalade samples. S1 sample was found best of all samples with respect to chemical composition. The analysis of chemical composition of S1 sample (malta juice: mango juice: pine-apple juice=2:1:1) was found as: moisture $27.71 \%$, ash $0.16 \%$, TSS $67.5 \%$, total sugar $66.2 \%$, acidity $0.90 \%$ and $\mathrm{pH} 2.8$. On the basis of sensory evaluation the S1 sample was the most acceptable among others in terms of color, flavor, texture and overall acceptability. Storage study was conducted on the mixed fruit marmalades for six months at room temperature $\left(23-30^{\circ} \mathrm{C}\right)$ and relative humidity 80 to $85 \%$. It was observed that TSS, pH and acidity of mixed fruit marmalades did not show any remarkable changes. Color and flavor were acceptable throughout six months of storage period. After six month of storage period small amount of mould and bacterial attack was observed in marmalade samples. The microbial count was low due to high acidity and proper storage of the samples. The microbial contamination was very low in sample $\mathrm{S} 1$ than other samples due to its highest acidity.
\end{abstract}

Keywords: Marmalade, Mixed fruit, Malta, Mango, Pineapple

\section{Introduction}

Marmalade is a product made from citrus fruit (usually) and is the jelly-like product made from properly prepared juice and peel, with sugar. It is concentrated to achieve its gel structure, similar to jelly, with approximately the same standards, except for the use of sliced peel. In another word, a good marmalade should be a jelly with pieces of fruit suspended therein and should not be merely a jam or butter. The principles of jelly making, therefore, apply also to the preparation of marmalade. Using of citrus peel adds extra nutrition to the marmalade and reduces the wastage of citrus fruits.

The pineapple is one of the very much popular fruits because of its excellent flavor, taste, color and nutritive value. Mango, the king fruit of Bangladesh is also popular because of its beautiful shape, color, flavor, taste and nutritive value. Per $100 \mathrm{gm}$ edible portion, the pineapple contents $96.6 \mathrm{gm}$ moisture, 0.1 $\mathrm{gm}$ minerals, $3.8 \mathrm{gm}$ fiber, $11.0 \mathrm{kcal}$ energy, $1 \mathrm{gm}$ protein, $0.8 \mathrm{gm}$ fat, $1.4 \mathrm{gm}$ carbohydrate, $22.0 \mathrm{gm}$ calcium, $4.3 \mathrm{gm}$ iron, $120 \mu \mathrm{gm}$ carotene, $0.09 \mathrm{mg}$ vit$\mathrm{B}_{1}, 0.024 \mathrm{mg}$ vit- $\mathrm{B}_{2}$ and $60 \mathrm{mg}$ vit-C. Similarly, per 100 gin edible portion, the mango contents $78.6 \mathrm{gm}$ moisture, $0.4 \mathrm{gm}$ minerals, $0.7 \mathrm{gm}$ fiber, $90.0 \mathrm{kcal}$ energy, $1 \mathrm{gm}$ protein, $0.7 \mathrm{gm}$ fat, $20.0 \mathrm{gm}$ carbohydrate, $16.0 \mathrm{gm}$ calcium, $1.3 \mathrm{gm}$ iron, 8300 $\mu \mathrm{gm}$ carotene, $0.10 \mathrm{mg}$ vit- $\mathrm{B}_{1}, 0.07 \mathrm{mg}$ vit- $\mathrm{B}_{2}$ and 41 $\mathrm{mg}$ vit-C (Begum, 2000).

Malta is a citrus fruit. It is a variety of orange family, botanically classified as Citrus reticulata. The malta is easily peeled with the fingers, starting at the thick rind covering the depression at the top of the fruit and can be easily split into even segments without squirting juice. This makes it convenient to eat, as utensils are not required to peel or cut the fruit.

Canned malta segments are peeled to remove the white pith prior to canning; otherwise, they turn bitter. Segments are peeled using a chemical process. First, the segments are scalded in hot water to skin; then they are bathed in a lye solution which digests the albedo and membranes. Finally, the segments undergo several rinses in plain water (Chopra et al. 1986).

Considering all the above factors an attempt was made to processing and to standardize the formulation of the mixed fruit marmalade using three ratio and to study the sensory attributes and shelf life to fulfill the specific objectives of this experiment.

\section{Materials and Methods}

The fully ripe healthy and fresh malta, pine-apple, mango fruits and sugar were procured from the local market. The juices of these fruits and malta peels were used in the experiment. Pectin, citric acid, 
equipments and other materials were used from the laboratory stock.

\section{Extraction/Preparation of pine-apple juice}

Extraction of pineapple juice was done by the following ways. Ripe and matured pine-apples were sorted. Crown was removed by twisting force using hand. The pine-apples were washed thoroughly by potable water. Peeling of pine-apples was done by a sharp knife. Cores of pine-apples were removed by a sharp knife. Pine-apples were cut into several small pieces to facilitate proper extraction of pine-apple juice. Pine-apple juice was extracted using a high quality juicer. The extracted juice was strained properly. Juice was pasteurized at $82-85^{\circ} \mathrm{C}$. After pasteurization juice was cooled properly. Juice was packed properly into high density polyethylene. The packed juice was kept in a freezer.

\section{Extraction of mango juice}

Extraction of mango juice was done by the following ways. Ripe and matured mangoes were sorted. The mangoes were washed thoroughly by potable water. Peeling of mangoes was done by a sharp knife. Stones of mangoes were removed using a sharp knife and eatable parts were pieced to facilitate the extraction of mango juice. Mango juice was extracted using a high quality juicer. The extracted juice was strained properly through a cloth. Juice was pasteurized at $85^{\circ} \mathrm{C}$. After pasteurization juice was cooled properly. Juice was packed properly into high density polyethylene. The packed juice was kept in a freezer.

\section{Extraction of malta juice}

Extraction of mango juice was done by the following ways. Ripe and matured maltas were sorted. Peeling of malta was done by hand. The separation and cleaning of segments was done by hand. Malta juice was extracted using a high quality juicer. The extracted juice was strained properly. Juice was pasteurized at $80^{\circ} \mathrm{C}$. After pasteurization juice was cooled properly. Juice was packed properly into high density polyethylene. The packed juice was kept in a freezer.

\section{Processing of malta peel}

Processing of malta peel was done by the following ways. Inner whitish portion of malta peel was removed by a sharp knife. Peels were cut into specific size of pieces. The pieces of malta peels were soaked into $60 \%$ sugar solution for overnight.

\section{Preparation of mixed fruit marmalade}

Preparation of mixed fruit marmalade was done by the following ways. All the required ingredients were weighed correctly. Sugar and pectin were mixed thoroughly. Malta, mango and pine-apple juices were added. The mixture was boiled up to $65^{\circ}$ brix (TSS). Malta peels were added. Citric acid was added. The mixture was boiled up to $67^{\circ}$ brix (TSS). The prepared marmalade was poured into sterile glass bottles immediately. The prepared marmalade was cooled properly. After then paraffining was done. The bottles were capped properly. The marmalades were stored at room temperature.

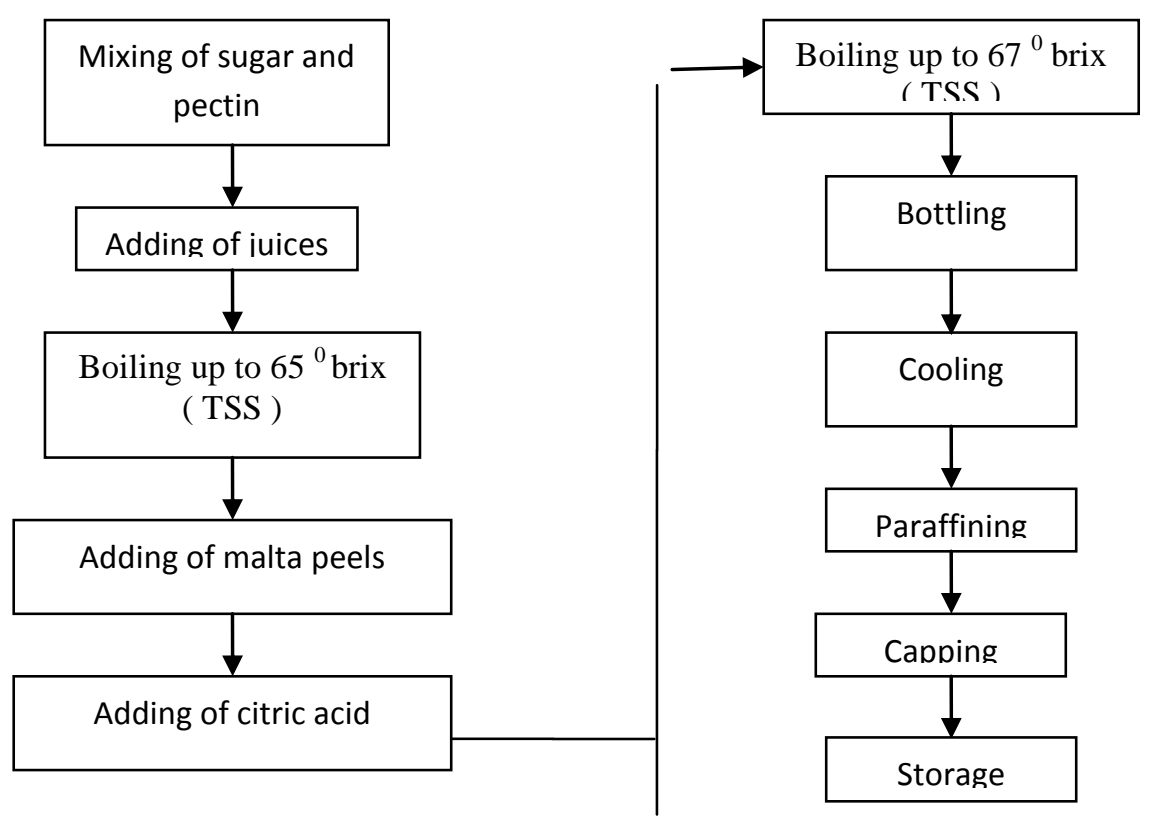

Fig 1: Processing steps for mixed fruit marmalade preparation 
Table 1. Formulation of mixed fruit marmalade

\begin{tabular}{|l|c|c|c|c|c|c|c|}
\hline Sample & Malta juice (g) & $\begin{array}{l}\text { Pine-apple juice } \\
(\mathbf{g})\end{array}$ & Mango juice (g) & Malta peel ( g ) & Sugar ( g ) & Pectin (g) & $\begin{array}{l}\text { Citric acid } \\
\text { (g) }\end{array}$ \\
\hline $\mathrm{S}_{1}$ & 200 & 100 & 100 & 50 & 550 & 6 & 5 \\
\hline $\mathrm{S}_{2}$ & 100 & 200 & 100 & 50 & 550 & 6 & 5 \\
\hline $\mathrm{S}_{3}$ & 100 & 100 & 200 & 50 & 550 & 6 & 5 \\
\hline $\mathrm{S}_{4}$ & 133 & 133 & 133 & 50 & 550 & 6 & 5 \\
\hline
\end{tabular}

\section{Product formulation of mixed fruit marmalade}

Mixed fruit marmalades were prepared with the following formula

\section{Chemical analysis}

The juices of malta, mango and pine-apple, mixed fruit marmalades were analyzed for: Moisture, Ash, Acidity, Vitamin-C, pH, Total soluble solids (TSS), Reducing sugar, Non-reducing sugar, Total sugar. Moisture and ash content were determined adopting AOAC (2002) method. Ranganna (1991) states the methods of reducing sugar and non-reducing sugar determination.

\section{Statistical Analysis}

The data were analyzed in Randomized Complex Block Design using Computer Program MSTATC. Duncan's Multiple Range Test was done to compute the storage condition variation.

\section{Sensory evaluation}

The consumer's acceptability of developed products was evaluated by a taste testing panel. The hedonic rating test was used to determine this acceptability. The score was used for judging the products. The panelists were selected from different social status. The panelists were asked to rate their acceptability for the product on a hedonic scale, 1 to 9 , ranging from "dislike extremely" to "like extremely". Some numerical values are assigned to each point on the scale to analyze the result using statistical methods. The results were evaluated by Analysis of Variance and Duncan Multiple Range Test (DMRT).

\section{Chemical changes}

In the same condition chemical analysis of mixed fruit marmalade such as moisture, TSS, ash, $\mathrm{pH}$, acidity, total sugar, reducing sugar and non-reducing sugar were observed.

\section{Microbiological study Counting of yeast and mould}

Yeast and mould count of mixed fruit marmalades were also determined according to the "Recommended method for the Microbiological Examination of Food", Published by American Public Health association (APHA, 1967).

\section{Determination of total viable bacteria}

For total viable count of bacteria present in mixed fruit marmalades, the experiment was done according to the method described in "Laboratory Methods in Food Microbiology" (Harrigan, 1998).

\section{Results and Discussion}

Mixed fruit marmalades were prepared from ripen malta, mango and pine-apple fruits. Different composition and acceptability of mixed fruit marmalades were investigated. The results of various experiments conducted during the study period are discussed below:

\section{Composition of fruit juices}

After extraction, the juices were processed for preparing mixed fruit marmalade and properly packed in appropriate packets. Then the samples were kept for microbial and storage studies. The compositions of fruit juices such as moisture, TS, TSS, reducing sugar, non-reducing sugar, total sugar, ash, $\mathrm{pH}$, acidity and vitamin $\mathrm{C}$ content are shown in table 2 . 
Table 2. Chemical composition of mango, pine-apple and malta juice

\begin{tabular}{|l|c|c|c|}
\hline Parameters & Mango juice & Pine-apple juice & Malta juice \\
\hline Moisture (\%) & 86.6 & 87.6 & 89 \\
\hline TS (\%) & 13.4 & 12.4 & 11 \\
\hline TSS (\%) & 13 & 12.5 & 10.1 \\
\hline Reducing sugar (\%) & 6.41 & 6.89 & 3.5 \\
\hline Non-reducing sugar (\%) & 5.63 & 4.89 & 2.5 \\
\hline Total sugar (\%) & 12.04 & 11.78 & 6 \\
\hline Ash (\%) & 0.4 & 0.3 & 0.5 \\
\hline pH & 3.78 & 3.63 & 3.1 \\
\hline Acidity (\% ) & 0.43 & 0.45 & 0.6 \\
\hline Vitamin-C (mg / 100 gm ) & 15.7 & 8.34 & 21 \\
\end{tabular}

The above analyses are almost similar to the findings reported by Anonymous (1984) and Hulme (1970).

\section{Chemical characteristics of mixed fruit marmalades}

According to formulation, sugar concentration of mixed fruit marmalades was prepared by mixing different ingredients. After preparation of mixed fruit marmalades the chemical compositions of the marmalades were determined. The compositions of mixed fruit marmalades have been shown in Table 3.

Table 3. Compositions of mixed fruit marmalades

\begin{tabular}{|l|l|l|l|l|l|l|l|l|l|}
\hline Sample & $\begin{array}{l}\text { Moisture } \\
(\boldsymbol{\%})\end{array}$ & $\begin{array}{l}\text { TSS } \\
(\boldsymbol{\%})\end{array}$ & $\begin{array}{l}\text { Reducing } \\
\text { Sugar }(\boldsymbol{\%})\end{array}$ & $\begin{array}{l}\text { Non-Reducing } \\
\text { Sugar }(\boldsymbol{\%})\end{array}$ & $\begin{array}{l}\text { Total } \\
\text { Sugar } \\
(\boldsymbol{\%})\end{array}$ & $\begin{array}{l}\text { Ash } \\
(\boldsymbol{\%})\end{array}$ & pH & $\begin{array}{l}\text { Acidity } \\
(\boldsymbol{\%})\end{array}$ & $\begin{array}{l}\text { Vitamin- C } \\
(\mathbf{m g} / \mathbf{1 0 0 g m})\end{array}$ \\
\hline S1 & 27.71 & 67.5 & 10.8 & 55.4 & 66.2 & 0.16 & 2.8 & 0.9 & 5.20 \\
\hline S2 & 27.16 & 67 & 10.35 & 55.45 & 65.8 & 0.12 & 2.82 & 0.86 & 3.32 \\
\hline S3 & 27.31 & 67 & 11.23 & 53.92 & 65.15 & 0.19 & 2.85 & 0.81 & 2.60 \\
\hline S4 & 26.63 & 67 & 12.32 & 51.78 & 64.10 & 0.26 & 2.87 & 0.74 & 4.03 \\
\hline
\end{tabular}

\section{Effect of different samples on the composition of marmalade}

The highest moisture content of mixed fruit marmalade was obtained from sample S1 and the lowest moisture content was obtained from sample S4. There was significant variation of moisture content among the sample S1, S2 and S3 (Table 3). The highest ash content of mixed fruit marmalade was obtained from sample S4 and the lowest ash content was obtained from sample S2 (Table 3).

Ascorbic acid (Vitamin C) content in mixed fruit marmalades were found very low compared to raw fruit juices. Because most of the ascorbic acid present in the pulp was destroyed during long heating at high temperature. Together with this vitamin-C is highly volatile micronutrient. The composition that was found may vary due to the variety, environment and maturity affect. The highest acidity content of mixed fruit marmalade was obtained from sample $\mathrm{S} 1$ and the lowest was obtained from sample S4 (Table 3).
Acidity content was non significant among sample S1, S2, S3 and S4.

The highest $\mathrm{pH}$ value of mixed fruit marmalade was obtained from sample $\mathrm{S} 4$ and the lowest was obtained from sample S1 (Table 3). The highest total soluble solids of mixed fruit marmalades were obtained from sample 67.5. The lowest was obtained from sample S2, S3, S4 (Table 3). i.e. the TSS content of sample S2, S3, S4 was same. There was a significant difference in TSS among the all samples. The component, which affects the taste of products, is the sugar content. The highest value was obtained from sample S1 and the lowest value was obtained from sample S4 (Table 3).

\section{Sensory evaluation of mixed fruit marmalade}

The different qualitative characters of prepared mixed fruit marmalades were examined organoleptically by a panel of 12 judges. (Four) samples with different formulations were evaluated by panelists for color, flavor, texture and overall acceptability using 1-9 point hedonic scale. It may be mentioned here that a 
two-way analysis of variance (ANOVA) was carried out and results revealed that there were significant ( $\mathrm{p}<0.05$ ) differences in color, flavor, texture and overall acceptability among the samples S1, S2, S3 and S4.

The colors of the samples were not equally acceptable. The DMRT test revealed that the color of S1 sample was more preferred and significantly different than other samples. Of the four samples sample S2 was inferior due to it's low mean score (7.00). The flavors of the samples were not equally acceptable. In the case of flavor, the DMRT test revealed that $\mathrm{S} 1$ was most preferred and securing highest mean score (8.083). The lowest secure mean score was (7.083) and the score was for the sample of S2 and significantly differed from the other samples. The textures and overall acceptability of the samples also were not equally acceptable. The DMRT test revealed that the texture of $\mathrm{S} 1$ sample was more preferred and significantly different than other samples. Of the four samples sample S2 was inferior due to it's low mean score (7.00). The DMRT test of the overall acceptability revealed that $\mathrm{S} 1$ sample was more preferred due to it's highest secured mean score (7.917) and significantly different than other samples. Of the four samples, sample S2 was inferior due to it's low mean score (7.00).

Table 4. Mean sensory score of 4 samples of marmalade.

\begin{tabular}{|c|c|c|c|c|}
\hline \multirow{2}{*}{ Sample } & \multicolumn{4}{|c|}{ Sensory attributes } \\
\hline & Color & Flavor & Texture & Overall acceptability \\
\hline $\mathrm{S} 1$ & $8.417^{\mathrm{a}}$ & $8.083^{\mathrm{a}}$ & $8.167^{\mathrm{a}}$ & $7.917^{\mathrm{a}}$ \\
\hline $\mathrm{S} 2$ & $8.000^{a b}$ & $8.000^{a b}$ & $7.917^{\mathrm{ab}}$ & $7.833^{a b}$ \\
\hline S3 & $7.833^{\mathrm{ab}}$ & $7.917^{\mathrm{ab}}$ & $7.833^{\mathrm{ab}}$ & $7.250^{\mathrm{ab}}$ \\
\hline $\mathrm{S} 4$ & $7.000^{b}$ & $7.083^{b}$ & $7.000^{b}$ & $7.000^{b}$ \\
\hline L.S.D $(\mathrm{P}<0.05)$ & 0.6859 & 0.6783 & 0.6052 & 0.6519 \\
\hline
\end{tabular}

\section{Storage studies of mixed fruit marmalade}

Mixed fruit marmalades were stored at ambient temperature $\left(27^{\mathrm{O}} \mathrm{C}\right.$ to $\left.34^{\mathrm{O}} \mathrm{C}\right)$ for a period of 6 months and quality parameters were assessed. The formulations were S1, S2, S3 and S4 which were examined at an interval of 30 days during the storage period. During storage the changes in TSS, acidity, $\mathrm{pH}$, vitamin- $\mathrm{C}$, moisture, ash, and sugar were observed. The analyses of the parameters were done according to standard analytical methods summarized by AOAC (2000) and Rangana (2003). Results are presented in Table 5. Some physical changes such as color, flavor and turbidity were observed.

\section{Effect of storage period on the composition of marmalade}

Moisture content of the formulated samples S1, S2, S3 and S4 was nearly constant up to 6 month of storage period. Very slight increase in moisture was occurred. It may be occurred due to slight imperfection in sealing or mechanical error in moisture determination by air oven. It was observed that total soluble solids (TSS) of mixed fruit marmalades did not show any remarkable change up to six month of storage period.

The acid content of fruit juices caused the hydrolysis of fruit sugar, which resulted the increase of reducing sugar during the storage period. Ewaidah (1992) reported that the increase in reducing sugar due to the hydrolysis of sucrose present in fruit juices. So the samples S1, S2, S3 and S4 showed the gradual increase in reducing sugar throughout the six months of storage period.

Insignificant variation was observed in non-reducing sugar of the formulations S1, S2, S3 and S4 throughout the six months of storage period (Table 5). Slide decrease in non-reducing sugar may be due to the conversion of some non-reducing sugar to reducing sugar through the process of glucogenesis. Sugar used in the manufacture of mixed fruit marmalade should be free from mesophillic bacteria, yeast and molds. Non-reducing sugar decrease rapidly when the product contains these types of bacteria, mold and yeast.

The total sugar of formulated samples S1, S2, S3 and S4 showed an insignificant variation throughout the 6 months of storage period (Table 5). This study is partially corresponding to the findings reported by Ewaidah (1992) who observed that the reducing sugar was increased due to the hydrolysis of sucrose. Ash content of formulated samples did not show any appreciable change during 6 months of storage period (Table 5). This is similar to the study that is partially in agreement with the findings reported by Akinyele et al. (1990). The author stated that ash was not significantly affected by processing and storage. 
Table 5. Study of chemical composition at different storage period of time.

\begin{tabular}{|c|c|c|c|c|c|c|c|c|c|}
\hline $\begin{array}{l}\text { Storage } \\
\text { period }\end{array}$ & Sample & Moisture (\%) & $\begin{array}{l}\text { TSS } \\
(\%)\end{array}$ & $\begin{array}{l}\text { Reducing sugar } \\
(\%)\end{array}$ & $\begin{array}{l}\text { Non-reducing } \\
\text { sugar } \\
(\%)\end{array}$ & $\begin{array}{l}\text { Total sugar } \\
(\%)\end{array}$ & $\begin{array}{l}\text { Ash } \\
(\%)\end{array}$ & pH & $\begin{array}{l}\text { Acidity } \\
\text { ( \% ) }\end{array}$ \\
\hline \multirow[t]{4}{*}{0 days } & S1 & 27.71 & 67.5 & 10.8 & 55.4 & 66.2 & 0.16 & 2.8 & 0.9 \\
\hline & S2 & 27.16 & 67 & 10.35 & 55.45 & 65.8 & 0.12 & 2.82 & 0.86 \\
\hline & S3 & 27.31 & 67 & 11.23 & 53.92 & 65.15 & 0.19 & 2.85 & 0.81 \\
\hline & S4 & 26.63 & 67 & 12.32 & 51.78 & 64.10 & 0.26 & 2.87 & 0.74 \\
\hline \multirow[t]{4}{*}{30 days } & S1 & 27.71 & 67.5 & 10.8 & 55.4 & 66.2 & 0.16 & 2.8 & 0.87 \\
\hline & S2 & 27.16 & 67 & 10.36 & 55.41 & 65.77 & 0.12 & 2.82 & 0.86 \\
\hline & S3 & 27.31 & 67 & 11.23 & 53.92 & 65.15 & 0.19 & 2.85 & 0.81 \\
\hline & S4 & 26.63 & 67 & 12.33 & 51.74 & 64.07 & 0.25 & 2.84 & 0.77 \\
\hline \multirow[t]{4}{*}{60 days } & S1 & 27.73 & 67.5 & 10.81 & 55.39 & 66 & 0.15 & 2.78 & 0.88 \\
\hline & S2 & 27.19 & 66.5 & 10.38 & 55.34 & 65.72 & 0.11 & 2.79 & 0.89 \\
\hline & S3 & 27.33 & 67 & 11.24 & 53.87 & 65.11 & 0.18 & 2.80 & 0.83 \\
\hline & S4 & 26.66 & 67 & 12.35 & 51.67 & 64.02 & 0.23 & 2.79 & 0.81 \\
\hline \multirow[t]{4}{*}{90 days } & S1 & 27.77 & 67 & 10.83 & 55.13 & 65.96 & 0.14 & 2.74 & 0.90 \\
\hline & S2 & 27.24 & 66.5 & 10.4 & 55.25 & 65.65 & 0.11 & 2.74 & 0.91 \\
\hline & S3 & 27.37 & 66.5 & 11.26 & 53.79 & 65.05 & 0.17 & 2.74 & 0.86 \\
\hline & S4 & 26.71 & 67 & 12.39 & 51.57 & 63.96 & 0.22 & 2.73 & 0.84 \\
\hline \multirow[t]{4}{*}{120 days } & S1 & 27.84 & 67 & 10.86 & 55.03 & 65.89 & 0.14 & 2.7 & 0.92 \\
\hline & S2 & 27.31 & 66 & 10.43 & 55.13 & 65.56 & 0.10 & 2.68 & 0.93 \\
\hline & S3 & 27.43 & 66 & 11.29 & 53.67 & 64.96 & 0.15 & 2.65 & 0.89 \\
\hline & S4 & 26.79 & 66.5 & 12.44 & 51.43 & 63.87 & 0.22 & 2.70 & 0.87 \\
\hline \multirow[t]{4}{*}{150 days } & S1 & 27.85 & 67 & 10.91 & 54.89 & 65.80 & 0.14 & 2.66 & 0.94 \\
\hline & S2 & 27.35 & 66 & 10.48 & 54.99 & 65.47 & 0.10 & 2.63 & 0.95 \\
\hline & S3 & 27.47 & 66 & 11.34 & 53.53 & 64.87 & 0.15 & 2.63 & 0.93 \\
\hline & S4 & 26.84 & 66.5 & 12.50 & 51.28 & 63.78 & 0.21 & 2.67 & 0.91 \\
\hline \multirow[t]{4}{*}{180 days } & S1 & 27.87 & 66.5 & 10.98 & 54.72 & 65.70 & 0.13 & 2.62 & 0.97 \\
\hline & S2 & 27.39 & 65.5 & 10.54 & 54.82 & 65.36 & 0.10 & 2.60 & 0.98 \\
\hline & S3 & 27.53 & 66 & 11.40 & 53.36 & 64.76 & 0.14 & 2.61 & 0.96 \\
\hline & S4 & 26.90 & 66 & 12.58 & 51.09 & 63.67 & 0.20 & 2.64 & 0.95 \\
\hline
\end{tabular}

Changes of acidity of mixed fruit marmalades have been shown. It was observed that the changes of acidity occurred slightly up to 180 days of storage.
This might be due to the fermentation or hydrolysis of sugar. $\mathrm{pH}$ of mixed fruit marmalades was slightly reduced throughout 180 days of storage period. The variation of $\mathrm{pH}$ occurred due to the variation of acidity during storage period at room temperature. 
Table 6. Storage studies of mixed fruit marmalades on some physical changes.

\begin{tabular}{|c|c|c|c|c|c|}
\hline \multirow{2}{*}{$\begin{array}{l}\text { Storage period } \\
\text { ( month ) }\end{array}$} & \multirow[b]{2}{*}{ Sample } & \multicolumn{3}{|l|}{ Observation } & \multirow[b]{2}{*}{ Remark } \\
\hline & & Color & Flavor & Turbidity & \\
\hline \multirow[t]{4}{*}{0} & $\mathrm{~S} 1$ & Light orange & Fresh & Clear & Good \\
\hline & $\mathrm{S} 2$ & Light orange & Fresh & Clear & Good \\
\hline & S3 & Light orange & Fresh & Clear & Good \\
\hline & $\mathrm{S} 4$ & Light brownish yellow & Fresh & Clear & Good \\
\hline \multirow[t]{4}{*}{1} & $\mathrm{~S} 1$ & Light orange & Fresh & Clear & Good \\
\hline & $\mathrm{S} 2$ & Light orange & Fresh & Clear & Good \\
\hline & S3 & Light orange & Fresh & Clear & Good \\
\hline & $\mathrm{S} 4$ & Light brownish yellow & Fresh & Clear & Good \\
\hline \multirow[t]{4}{*}{2} & $\mathrm{~S} 1$ & Light orange & Fresh & Clear & Good \\
\hline & $\mathrm{S} 2$ & Light orange & Fresh & Clear & Good \\
\hline & S3 & Light orange & Fresh & Clear & Good \\
\hline & $\mathrm{S} 4$ & Light brownish yellow & Fresh & Clear & Good \\
\hline \multirow[t]{4}{*}{3} & $\mathrm{~S} 1$ & Light orange & Fresh & Clear & Good \\
\hline & $\mathrm{S} 2$ & Light orange & Fresh & Clear & Good \\
\hline & S3 & Light orange & Fresh & Clear & Good \\
\hline & S4 & Light brownish yellow & Fresh & Clear & Good \\
\hline \multirow[t]{4}{*}{4} & S1 & Light orange & Fresh & Clear & Good \\
\hline & $\mathrm{S} 2$ & Light orange & Fresh & Clear & Good \\
\hline & S3 & Light orange & Fresh & Clear & Good \\
\hline & $\mathrm{S} 4$ & Light brownish yellow & Fresh & Clear & Good \\
\hline \multirow[t]{4}{*}{5} & S1 & Light orange & Fresh & Clear & Good \\
\hline & $\mathrm{S} 2$ & Orange & Fresh & Clear & Good \\
\hline & S3 & Orange & Fresh & Clear & Good \\
\hline & S4 & Brownish yellow & Fresh & Clear & Good \\
\hline \multirow[t]{4}{*}{6} & $\mathrm{~S} 1$ & Orange & Fresh & Clear & Good \\
\hline & $\mathrm{S} 2$ & Orange & Fresh & Clear & Good \\
\hline & S3 & Orange & Fresh & Clear & Good \\
\hline & $\mathrm{S} 4$ & Brownish yellow & Faint off flavor & Clear & Fair \\
\hline
\end{tabular}

Sample S2 and S3 changed to orange color from their light orange color in fifth and sixth month of storage period. Sample S1 changed to orange color from it's light orange color in sixth month of storage period. Sample S4 changed to brownish yellow color from it's light brownish yellow color in fifth and sixth month of storage period (Table 6). Faint off flavor was found in the case of S4 samples in sixth month of storage period (Table 6).

\section{Microbiological study of mixed fruit marmalades}

\section{Effect of total viable bacteria on different samples of mixed fruit marmalades}

The study was performed by Standard Plate Count Method (SPC). The viable bacterial load was not uniform. The total viable bacteria count $(\mathrm{cfu} / \mathrm{ml})$ was counted. The total no. of viable bacteria was counted multiplying the colony forming unit (cfu) with dilution number. The total numbers of viable bacteria in different samples have been shown in Table 7. The S4 sample showed maximum total viable bacteria and sample S1 and S2 sample showed minimum viable count. The total viable bacteria were reduced for the high acidity of the samples.

Table 7. Total number of viable bacterial count ( $\log \mathrm{cfu} / \mathrm{ml}$ ) after incubation of 48 hours at $32^{\circ} \mathrm{C}$

\begin{tabular}{|c|c|}
\hline Sample & Bacterial count $(\log \mathbf{c f u} / \mathbf{m l})$ \\
\hline S1 & 2.00 \\
\hline S2 & 2.00 \\
\hline S3 & 2.30 \\
\hline S4 & 2.48 \\
\hline
\end{tabular}


Effect of total moulds on different samples of mixed fruit marmalades

The number of mould was found in the mixed fruit marmalade have been shown in Table 08. The number of mould counts was found maximum in sample S4.
On the contrary, the number of mould was found less in $\mathrm{S} 1$ sample. These results revealed that the higher $\mathrm{pH}$ value of the samples supported higher mould count.

Table 8. Total count of mould ( $\log \mathrm{cfu} / \mathrm{ml}$ ) after incubation of 72 hours at $32^{\circ} \mathrm{C}$

\begin{tabular}{|c|c|}
\hline Sample & Mould count (log cfu / ml ) \\
\hline S1 & 2.30 \\
\hline S2 & 2.48 \\
\hline S3 & 2.60 \\
\hline S4 & 2.70 \\
\hline
\end{tabular}

\section{References}

Akinyele, L. O.; Keshinro, O. and Aminnawo, O. O. 1990. Nutritional losses during and after proscessing of pincapples and oranges. Food Chemistry, 37: (3), 181-188.

American Public Health Association. 1992. In: Speck, M.L. ed., Compendium of Methods for the Microbiological Examination of Foods. Inter society agency Committee on Microbiological Methods for Foods. A.P.H.A. Washington, 734.

Anonymous 1984. Cited from under graduate project report on the studies on processing and preservation of pineapple juice. Department of Food Technology and Rural Industries, BAU, Mymensing, p. 2-3.

AOAC, 2002. Official Methods of Analysis. 17th Edn., AOAC, Washington DC.

AOAC. 2000. Official Methods of Analysis of the Association of Official Analytical Chemists. $15^{\text {th }}$ Edition. Washington, DC.

Begum Z. A. 2000. Food Technology. Dept. of Food Technology and Rural Industries, BAU. Jaman Printers, 14, Gangadas Guha Road, Mymensingh,pp.20.
Chopra R. N.; Nayar, S. L. and Chopra, I. C. 1986. Glossary of Indian Medicinal Plants (Including the Supplement). Council of Scientific and Industrial Research, New Delhi

Ewaidah 1992. Studies on commercial canned juice produced locally in Saudi Arabia III. Physicochemical organoleptic and microbiological assessment Food Chemistry, 44: 2.

Harrigan, W.F. 1998. Laboratory Methods in Food Microbiology. Academic Press, San Diego.

Hulme, A. C. 1970. the Biochemistry of fruit and their products. Academic press Inc. 1td, London.1:1.

Rangana, S. 2003. Manual of Analysis of Fruits and Vegetable Products. Tata McGraw-Hill Co. Ltd., New Delhi. 2-95, 634.

Ranganna, S. 1991. Handbook of Analysis of Quality Control for Fruit and Vegetable Products. 2ed. Tata McGrawHill Pub. Co. Ltd. New Delhi. 